\title{
Stomatheraphy: influences and repercussions on the professional career
}

\author{
Estomaterapia: influências e repercussões na carreira profissional
}

Estomaterapia: influencias y repercusiones em la carrera profesional

Lais Del'Moro Cespedes Wojastyk ${ }^{1, *}$, Maria Ângela Boccara de Paula ${ }^{1,2}$, Merielen Neves Brajão Prado ${ }^{1}$

ORCID IDS

Wojastyk LDMC (D) https://orcid.org/0000-0003-3966-2696

Paula MAB (D) https://orcid.org/0000-0002-7438-9595

Prado MNB (D) http://orcid.org/0000-0002-0995-886X

\section{HOW TO CITE}

Wojastyk LDMC; Paula MAB; Prado MNB Estomaterapia: influências e repercussões na carreira profissional. ESTIMA, Braz. J. Enterostomal Ther., 2020, 18: e2020. https://doi.org/10.30886/estima.v18.883_IN

\begin{abstract}
Objective: To analyze the influences and repercussions of enterostomal therapy on the career of nurses. Methods: Descriptive, exploratory study with quantitative approach, conducted in 2014. The sample consisted of 29 nurses graduated from the Nursing School of the University of São Paulo and the University of Taubaté. The data were collected through a questionnaire and analyzed by SPHINXR software. The results were discussed in the light of the literature on the subject. Results: The continuity of the studies provided the nurse a career with promotions, management positions or even a career redirection. The work environment influenced the achievement of the specialty (21/79\%). The participants worked in several types of institutions and their positions were diverse, thus presenting options for those who want to pursue a career in the area. Conclusion: The job market, as well as the environment in which the nurse is inserted, most of the time plays a defining role when the subject is the choice of a specialization.
\end{abstract}

DESCRIPTORS: Nursing; Specialties, nursing; Enterostomal therapy.

\section{RESUMO}

Objetivo: Analisar as influências e repercussões da estomaterapia na carreira de enfermeiros. Métodos: Estudo de caráter descritivo, exploratório com abordagem quantitativa, realizado no ano de 2014. A amostra foi constituída de 29 enfermeiros egressos do curso de especialização em enfermagem em estomaterapia há mais de dez anos da Escola de Enfermagem da Universidade de São Paulo e da Universidade de Taubaté. Os dados foram coletados através de questionário e analisados pelo software SPHINX R. Resultados: A continuidade dos estudos proporcionou ao enfermeiro uma carreira com promoções, cargos gerenciais ou ainda um redirecionamento da carreira. O ambiente de trabalho influenciou na realização da especialidade (21/79\%). Os participantes atuavam em vários tipos de instituições e seus cargos eram diversos, apresentando assim opções para quem quer seguir carreira na área. Conclusão: 0 mercado de trabalho, assim como o ambiente que o enfermeiro está inserido, na maioria das vezes tem papel definidor quando o assunto é a escolha de uma especialização.

DESCRITORES: Enfermagem; Especialidades de enfermagem; Estomaterapia.

\footnotetext{
1. Universidade de Taubaté - Curso de Enfermagem em Estomaterapia - Departamento de Pós-Graduaça Taubaté (SP) - Brazil.

2. Associação Brasileira de Estomaterapia: Estomias, Feridas e Incontinência - São Paulo (SP) - Brazil.

*Correspondence author: lais.delmoro@hotmail.com

Received: May 5, 2020 | Accepted: Aug. 17, 2020
} 


\section{RESUMEN}

Objetivo: Analizar como las influencias y repercusiones de la estomatoterapia en la carrera de las enfermeras. Métodos: Estudio exploratorio descriptivo con enfoque cuantitativo, realizado en 2014. La muestra consistió en 29 enfermeras graduadas de un curso de especialización en enfermería de estomatoterapia hace más de diez años de la Escuela de Enfermería de la Universidad de São Paulo y la Universidad de Taubaté. Dados colectados por medio de cuestionario y analizados el software SPHINX y los resultados se discutieron a la luz de la literatura sobre el tema. Resultados: La encuesta de herencia proporcionan a las enfermeras una carrera con promociones, cargas gerenciales o incluso una redirección de carrera. El ambiente de trabajo era para la mayoría de los participantes (21/79\%) influencia en la decisión de realizar la especialidad. Los participantes trabajaron en varios tipos de instituciones y sus posiciones eran diversas, presentando así opciones para aquellos que desean seguir carreras en el área. Conclusión: El mercado laboral, así como el entorno en el que se insertan las enfermeras, a menudo tienen un papel decisivo a la hora de elegir una especialización.

DESCRIPTORES: Infección del sitio quirúrgico; Pediatría; Cirugía del corazón Estomaterapia.

\section{INTRODUCTION}

The need to complete and update the learning obtained in the undergraduate course makes the nurse to seek specialization. Besides building his professional career, the nurse, when becomes a specialist, tends to offer quality assistance and a practice based on scientific evidence ${ }^{1}$.

In career development, it is necessary to adapt personal needs to those of the work environment. The challenge is to respond to personal demands and aspirations with the needs of the institutions where the professional works. As the career develops, the person seeks answers to questions regarding his talents, skills and competence areas, strengths and weaknesses, reasons, needs, goals in life and main values. By answering these questions, the nurse builds up self-concepts, which gradually begin to function as true guides or anchors, and define career choices ${ }^{2}$.

In 1980, the World Council of Enterostomal Therapists (WCET) established enterostomal therapy as an exclusive specialty for nurses worldwide. An enterostomal therapist nurse is defined as one who has knowledge, specific training and skills for the care of patients with ostomy, who have acute and chronic wounds, fistulas and anal and urinary incontinence ${ }^{3,4}$.

The specialty was introduced in Brazil in the 1980s when some nurses graduated from schools abroad. In 1990, the first specialization course in enterostomal therapy nursing in the country was held at the Escola de Enfermagem da Universidade de São Paulo (EEUSP) and in 2000 the second course of the state of São Paulo at the Universidade de Taubaté (UNITAU) ${ }^{5}$.
The competencies and influences necessary to work in the job market in the area of enterostomal therapy are factors that characterize and represent the development and growth of the specialty in nursing. Enterostomal therapy specialization courses must follow the criteria established by WCET and the Associação Brasileira de Estomaterapia: Estomias, Feridas e Incontinências (SOBEST) to provide comprehensive, critical and reflective training6.

In order to investigate the influences and repercussions of enterostomal therapy on the career of nurses and to know which paths were chosen, this study was based on the need to explore the elements that drove the search for this specialty and how the repercussions on the professional career were developed.

\section{OBJECTIVE}

To know the main influences and repercussions of enterostomal therapy in the career of enterostomal therapist nurses.

\section{METHODS}

This study is characterized as descriptive, exploratory with a quantitative approach, developed in the educational institutions EEUSP and UNITAU. The data collection occurred from May to October 2014.

The research project was approved by the Research Ethics Committee of the Universidade de Taubaté (Opinion 1085007) in accordance with the guidelines 
and standards governing research on human beings, CNS Resolution 466/127.

The recruitment of participants was made from lists of nurses who completed the specialization course in enterostomal therapy, provided by the directors of educational institutions. The inclusion criteria of the research subjects were: enterostomal therapist nurses who graduated for ten years or more; nurses who had the registrations updated in the educational institutions for contact; enterostomal therapist nurses who agreed to participate in the research. The choice of professionals graduated ten years or more ago was made due to the need of experience in the field.

Once the list was composed, the number of 289 enterostomal therapist nurses was defined by the inclusion criteria. After contact attempt via phone and e-mail, 51 nurses were reached with the updated data. The first approach to find respondents was made by the researchers via telephone, requesting voluntary participation and willing to clarify possible doubts. Out of 51 questionnaires, 29 were returned and validated, characterizing the final sample. A second contact was made via e-mail from the researchers to the individuals, by sending the informed consent form to acknowledge the objectives of the study and the conditions for completing the research instrument; the form was also sent requesting that all documents were answered and returned to the researchers within a maximum of ten days. The form for data collection was developed by the researchers without prior validation, consisting of nine closed questions and one open question.
Sociodemographic data were collected regarding education, workplace, working time, as well as data regarding perceptions and influences on the professional career.

Later, with the return of the completed forms, the data were analyzed using the software SPHINX ${ }^{\mathrm{R}}$ and discussed in the light of the literature on the subject. SPHINX ${ }^{\mathrm{R}}$ is a software for quantitative and qualitative data analysis that includes research in all its stages: design and editing of the questionnaire, entry of the answers and verification and static analysis as simple and cross tabulations, uni-, bi- and multivariate data analysis ${ }^{8}$.

\section{RESULTADOS}

Regarding the characterization data of the participants, of the 29 (100\%) participants who responded, four (14\%) were between 35 and 40 years old, six (21\%) between 40 and 45 years old, four (14\%) between 45 and 50 years old, eight (27\%) between 50 and 55 years old, six (21\%) between 55 and 60 years old and one (3\%) was over 60 years old.

Regarding the gender of the participants, 28 (97\%) were female and $1(3 \%)$ was male.

Of the participants who answered the questionnaire, 19 (66\%) completed graduate education in enterostomal therapy at the Universidade de São Paulo (USP) and 10 (34\%) at UNITAU. The course completion date of the research participants is described in Fig. 1.

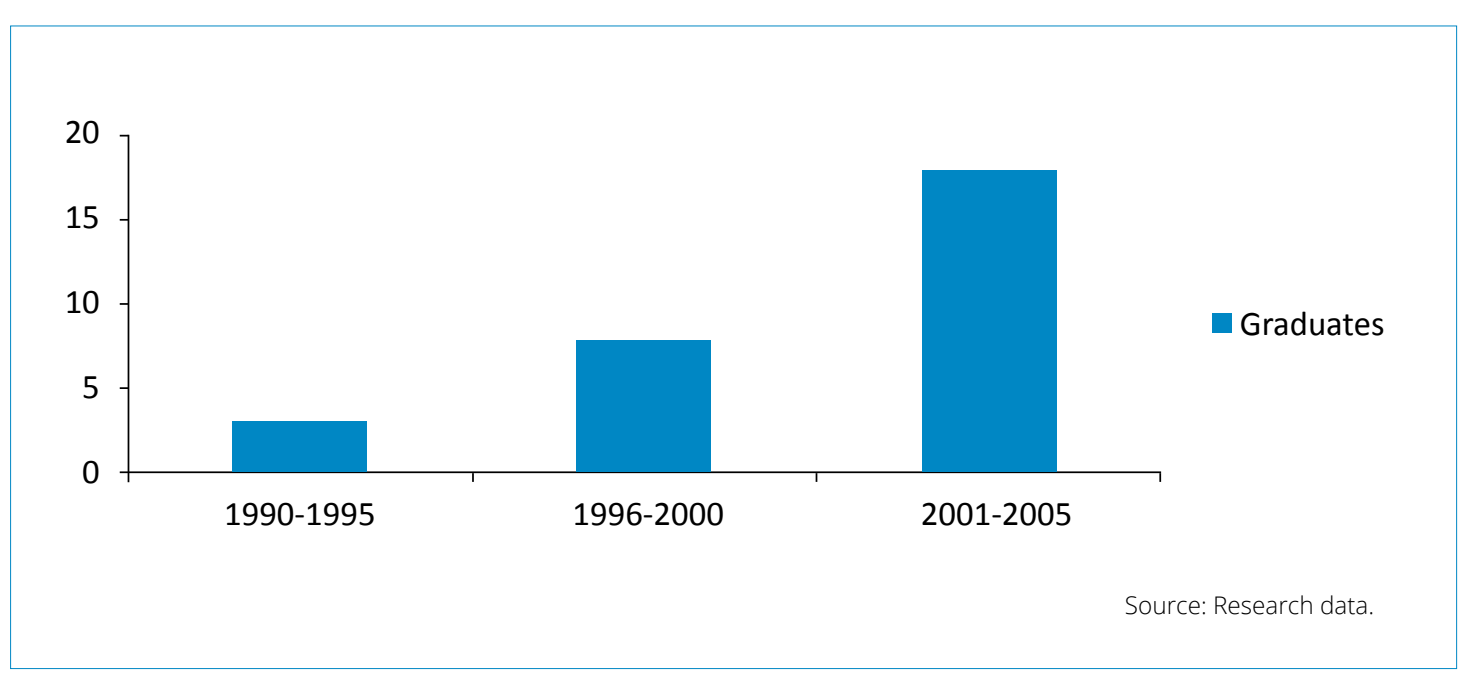

Figure 1. Distribution of participants according to completion date of graduate course in enterostomal therapy, São Paulo, 2019. 
Among the participants, 12 (41\%) completed more than one graduate course - of which 8 (28\%) completed two or more specialization courses -, 8 (28\%) only enterostomal therapy and 1 (3\%) did not answer this question. The specialties reported by the participants were: nursing teaching, hospital infection control, dermatology, public health, occupational health nursing, health service management, oncology, psychiatry, adult health, business management, epidemiology, clinical research, geriatrics, acupuncture, emergency, home care, auditing and psychopedagogy.

Among the participants, 24 (83\%) were working at the moment and $5(17 \%)$ were not performing any paid activity, of which 2 (7\%) participants are already retired. Table 1 shows the description of the activities performed individually.

Table 1. Distribution of participants according to professional activity. São Paulo, 2019.

\begin{tabular}{|c|c|c|}
\hline Position & Quantity & Percentage \\
\hline Enterostomal therapist & 6 & $25 \%$ \\
\hline Professor & 4 & $17 \%$ \\
\hline Nursing assistant & 3 & $13 \%$ \\
\hline Senior nurse & 2 & $9 \%$ \\
\hline Home care owner & 1 & $4 \%$ \\
\hline Assistance coordinator & 1 & $4 \%$ \\
\hline Scientific coordinator & 1 & $4 \%$ \\
\hline Nursing supervisor & 1 & $4 \%$ \\
\hline Self-employed nurse & 1 & $4 \%$ \\
\hline Commercial technical advisor & 1 & $4 \%$ \\
\hline Marketing technical advisor & 1 & $4 \%$ \\
\hline Scientific marketing manager & 1 & $4 \%$ \\
\hline Technical director of health service & 1 & $4 \%$ \\
\hline Total & 24 & $100 \%$ \\
\hline
\end{tabular}

Source: Research data.

Regarding the participants' workplace, 8 (33\%) worked in companies that manufactured medical products, 5 (21\%) were self-employed, 5 (21\%) worked in hospitals, $4(17 \%)$ worked in outpatient clinics and $2(8 \%)$ in educational institutions.

As for the career and professional influences, the data showed that the main influence for which the participant chose to do a specialization course in enterostomal therapy was mostly the affinity for the field (49\%). Other motivations were: the choice for the position or the function they occupied at the time (31\%) and the conviviality with other enterostomal therapist nurses (17\%).

Regarding the areas of enterostomal therapy with which the participants had more affinity at the time of choosing the specialty, 22 (57\%) reported to work with wounds, 15 (39\%) participants reported to work with ostomies and only $2(4 \%)$ to work with incontinence. It should be noted that participants could point out more than one alternative in this question.

When asked about the reason that directed them to the enterostomal therapy nursing course, 11 (32\%) participants reported that the reason was the labor market, 8 (28\%) that they had academic purposes, 5 $(22 \%)$ reported that the reason was the need to work in the area, $3(12 \%)$ reported that they wanted to provide better care to the people they assisted, 1 (3\%) reported that the new challenges that the specialty could provide and, 1 (3\%) had personal reasons.

In the question that asked if any participant was influenced by someone in the choice of the specialty, 18 (62\%) participants answered yes and 11 (38\%) no. Regarding the people who influenced their choice, 9 (50\%) participants answered that other enterostomal therapist nurses were responsible, 4 (23\%) that were 
influenced by coworkers, 3 (17\%) by their managers and $2(10 \%)$ by friends.

Among the participants, 18 (62\%) reported not having received any incentive from the institution where they worked to take the specialization course; on the other hand, 11 (38\%) participants informed that their work encouraged them. These incentives were: absence without wage discount, $50 \%$ of the monthly tuition paid by the institution, permission to leave the workplace to take the course, payment of road tickets, change of working hours and full tuition paid by the institution.

Regarding the work environment having influenced the choice of specialty, 23 (79\%) participants answered affirmatively and 6 (21\%) negatively. Among the participants who answered yes, 21 (92\%) reported that they related to the practice of caring for people with ostomies, wounds and/or incontinence, 1 (4\%) reported that the work environment influenced him, because there was an institutional demand for the creation of a enterostomal therapy clinic and 1 $(4 \%)$ answered that the work environment influenced him, because the realization of the specialty was a request from the management.

When asked about the career direction after specializing in enterostomal therapy, 24 (83\%) participants responded that there were changes and $5(17 \%)$ responded that the career direction had no changes after completing the specialty. Regarding the changes in career direction, 7 (27\%) responded that they were promoted, $6(24 \%)$ that they changed the institution where they worked, 5 (21\%) that they became self-employed professionals, 3 (11\%) that they became teachers in the area, 3 (11\%) that they oriented their career to research in enterostomal therapy, 1 (3\%) that created a graduate course in enterostomal therapy and $1(3 \%)$ that started an enterostomal therapy service. In this question, the 24 participants who responded positively pointed out more than one alternative.

Of the 5 (100\%) participants who responded that there was no change in career direction after specialization, all reported staying in the same function or position as the reason.

In the question regarding employment proposals from colleagues and teachers during graduate studies, 26 (90\%) participants reported that they did not receive a job proposal and $3(10 \%)$ responded that they did receive a job proposal. Of these, all were classmates.

When asked about the inclusion of functions directly related to enterostomal therapy in their professional practice after the completion of the specialty, 19 (66\%) participants responded that their function included general nursing care and care of people with wounds, ostomies and/or incontinence, 9 (31\%) reported to work exclusively with people with wounds, ostomies and/or incontinence and 1 (3\%) reported that their function was not directed to the care of people who needed specialized attention in the area.

When asked if they received any direction for their career as an enterostomal therapist after completing the specialty, 18 (62\%) participants answered no and 11 (38\%) yes. Among those who received some kind of career direction, 5 (46\%) reported that they received direction from teachers, 4 (36\%) from colleagues, 1 (4\%) participant received classes on entrepreneurship and 1 (4\%) received orientation in congresses.

Regarding the acquisition of new knowledge, 28 (97\%) participants responded that they were doing it on a regular basis. This upgrade has been carried out in different ways, as described in Table 2. The participants also pointed out more than one alternative in this question.

Table 2. Distribution of participants according to the update method. São Paulo, 2019.

Way to keep the knowledge up to date
Congresses and symposiums
Journals and upgrade courses
Books
Master's and doctorate degree
International events

Source: Research data. 
When asked if they believed they had a consolidated career as enterostomal therapists, 18 (62\%) participants answered yes and 11 (38\%) no. Among the participants who answered that they believed they had a consolidated career, $9(28 \%)$ stated that they considered it by their academic education, 8 (25\%) by the incentive at work, 6 (18\%) due to the career plan established at the institution they worked for, 4 (12\%) answered that the incentive of family members was extremely important for career continuation, 2 (7\%) that determination was an important fact in the consolidation, other reasons pointed out by the professionals, such as: personal investment, contact with companies that manufacture medical products, willpower, contact with SOBEST and scientific publications in the area.

In the open question in which participants reported what their plans were for the future professional, 6 (20\%) reported having no plans, 5 (17\%) wanted to continue in the same function, 4 (14\%) wanted to pursue their master's and/or doctorate, 2 (7\%) wanted to expand their knowledge, 2 (7\%) wanted to continue participating in SOBEST and other associations, 2 (7\%) wanted to form new enterostomal therapists and $2(7 \%)$ to created specialized services in enterostomal therapy. Other plans were cited, such as: improving their knowledge in home care enterostomal therapy, assisting patients in an autonomous way, assisting in research orientation, participating in more events, creating a blog, setting up a third party team to act, publishing research, continuing to develop the role of educator, returning to the job market, increasing the clinic's productivity, continuing to carry the banner of enterostomal therapy, creating a distance learning graduate course, performing consulting after retirement and 1 (3\%) participant did not answer this question. It is worth noting that the respondents mentioned more than one plan for the future.

\section{DISCUSSION}

The population researched, consisting mostly of enterostomal therapist nurses, was between 40 and 60 years old. This predominant age group was expected, since the objective of the study was to know the influences on the career of enterostomal therapist nurses with more than 10 years of completion of the specialization course.

In general, these data state that the requirements for graduate courses have increased in the job market for nursing professionals, with emphasis, at least, for specialization courses, which, in some institutions, are prerequisites for admission ${ }^{3}$.

A survey conducted by Fiocruz in partnership with the Brazilian Federal Nursing Council (Cofen) shows that $80 \%$ of nurses in Brazil have a graduate degree, of which $72.8 \%$ have a specialization'.

The great challenge for professional education is the development of individual autonomy in relation to the collective needs of society. Formal education must be able to give a vision of the whole, both in terms of interdependence and from the perspective of transdisciplinarity, in addition to enabling the construction of social change networks with the consequent expansion of individual and collective consciousness ${ }^{10}$.

Still regarding work, the rate of enterostomal therapist nurses in this study at working age who were not working was slightly below the national rate for July 2019, which was $12.5 \%$, according to data from the Instituto Brasileiro de Geografia e Estatística (IBGE) ${ }^{11}$.

Facing the current economic scenario, the enterostomal therapist nurse, as well as the other nurses, finds it difficult to move up the career ladder or even to get the first job. Many times, specialized professionals end up performing specialized assistance together with generalist nursing, thus creating a cost reduction for the institution where they work, but often generating professional frustration and underpaid salary.

As for the participants' field of work, it was divided into: medical product companies, hospitals, selfemployment, outpatient and educational institutions.

The scope of action of the enterostomal therapist is very broad, whether in the area of care, teaching, research, administration of health institutions and teaching, technical consulting in companies of medical products and advisory and consulting in specialized assistance (wounds, ostomies and incontinence) and projects aimed at new outpatients or nursing clinics. The enterostomal therapist can work in public and private services, ambulatory, specialized clinics, and home care as well as have his own company. There are those who have chosen to work independently, often at home, performing the nursing consultation and providing guidance and care.

In addition, it is possible to work in a medical company, multinational companies that produce devices 
for various injuries that affect the skin, devices for ostomy and incontinence treatment, and hospital supplies in general. This role is still under construction with the definition of the competences of the enterostomal therapist nurse in the sector ${ }^{3}$.

Another percentage of participants worked autonomously. The growth of scientific knowledge and new technologies in health increases the space for the autonomous activity of nurses, who, mainly from the 1980s on, began to tread new paths in the field of assistance and health care. Thus, the hospital area and public health are no longer the only alternatives within the job market for nurses ${ }^{12}$.

The autonomous activity gains greater amplitude in the practice of nursing in nursing clinics, specially services created for the attendance and some nursing cares that can be performed in extrahospital environment, mainly those related to the specialized cares, highlighting those that demand a specific knowledge and those centered in aspects not so widely publicized in the professional and educational practice, such as enterostomal therapy ${ }^{12}$.

A study conducted in Asia, showed that Chinese enterostomal therapists perform a variety of models of care, especially in the hospital environment, where they are responsible for patients with ostomies, wounds and incontinence, in addition to assisting in the continuing education of the nursing department, also attending outpatient clinics ${ }^{14}$.

Among the areas of action of enterostomal therapist nurses, the majority of participants responded to have affinity with wounds and ostomies, respectively, and a minority has affinity with the area of incontinence. These data corroborate another study that shows that $96 \%$ of the individuals work with wounds, $66 \%$ with ostomies and $30 \%$ with incontinence ${ }^{14}$.

In general, the tendency of professional enterostomal therapists to the area of ostomy and wounds can be perceived in practice, which can be explained by the demand of the clientele with this type of need. However, the area of incontinence treatment is gaining prominence among enterostomal therapists.

These data were confirmed in a survey carried out in 2016, in which there was a greater role of enterostomal therapists in the care of people with wounds. This fact can be linked to the professional identity of the nurse, because the care of people with wounds is a tradition in nursing ${ }^{3}$.
In the context of nursing specialties in Brazil, enterostomal therapy has been standing out, facing challenges and building its social representation in several fields of action. A positive trend can be observed regarding the evolution of the specialty, as the awareness of the category, organization, constant scientific research and technological development are achieved, which together are factors that characterize and represent milestones for the development, growth and projection of enterostomal therapy in Brazil ${ }^{4}$.

A study highlighted the importance of promoting specialist nurses, in other countries called advanced practice nurses, so that they can perform in practice all their knowledge in the area they have chosen, but there are challenges to this achievement, such as variability in education and certifications, different educational requirements and degrees, different scope of work, among others ${ }^{15}$.

The data show that the particular desires of the participants and the demands of the work institutions are interconnected when it comes to pursuing a professional career.

The specialists in nursing, due to the varied needs in health, ended up realizing in the daily practice that the knowledge must be constantly updated in order to be able to take care of the requirements of the clientele and the job market, that require fast and precise renewal in the way of thinking and acting of the professionals. They are faced with diverse and paths and fields of action and a range of possibilities at different levels of complexity, not only related to clinical practice, but also in the administrative, educational, research and professional development areas ${ }^{12}$.

The realization of a graduate course may be related to the desire to achieve a distinguished position in the job market and ascension to certain positions. Also because of the demands of this environment, especially in large urban centers ${ }^{14}$.

In a survey conducted in 2015, most of the nursing professionals consulted consider that their graduate academic education is not appropriate for their work activity. This situation occurs despite the fact that most of them claim to have carried out continuous qualification courses or have participated in congresses, conferences or seminars, proving that the continuous qualification that the consulted professionals receive is not adequate to their work needs, nor their academic formation ${ }^{1}$. 
The responsibility for reconciling the individual needs of each worker with those of the organizations in which he or she is inserted should be shared between the occupants of individual careers, the organization represented by the instance of management and human resources, managers and, perhaps, other partner institutions, such as universities and government agencies, which can be important elements in mediating this role ${ }^{5}$.

Most participants reported that there were changes in career direction after the graduate course.

It is essential to consider that the knowledge of how health professionals, in particular nurses, have been absorbed by job market constitutes an important parameter for educational institutions that have the role of training people to meet not only the job market, but also to respond to social and health demands and, especially, contribute to the transformation of society ${ }^{12}$.

If an individual does not know his needs and inclinations, the career will hardly be constructively managed. The individual needs to communicate clearly with peers and superiors responsible for his assessment to make intelligent choices. It is unrealistic to expect managers of organizations to understand their employees so well that they will make decisions about careers that are valid for those concerned ${ }^{4}$.

The most diverse charges for a quality professional performance can generate motivation in nurses to seek specialized knowledge and base the so idealized assistance of excellence to the human being. Facing this scenario, the specialist nurses are aware of the need to keep themselves updated and active in the scientific environment, participating in congresses, giving lectures, giving classes and carrying out scientific productions to keep their space within the area of expertise ${ }^{4}$.

Thus, without the pretension of having exhausted the subject, the practice of the specialist in diversity appears as an important dimension in the context and path of the profession. To perceive the importance and the difference of the care based on the union of the technician with the "human", the necessity of constant updating, in a formal and informal way, to be focused on the transformations, to the production of new researches and, consequently, to the quality of life of the whole person, define the necessary trajectory for the specialist nurses to remain active and necessary in the context of the health, contributing for the blossoming of a new representation of nurses in the society and their recognition as unique, fundamental and essential professionals in the context of the health professions ${ }^{12}$.

In a study conducted with physicians on perception of success and quality of life, the specialists presented the highest average satisfaction with regard to quality of life at work and perception of success in the career, linking this to the longer period of professional training, increased salary, technical autonomy, power and professional prestige ${ }^{16}$.

In the open question, when asked about the future of the career, the enterostomal therapist nurses were optimistic and presented many plans, looking for personal improvement, expansion of the graduation in enterostomal therapy and personal satisfaction.

Regarding the limitations in the execution of the research, the reduced number of nurses with updated data at the respective universities restricted the number of participants.

\section{CONCLUSION}

Amid a scenario in which changes in the way work happens at an accelerated pace, it is required from enterostomal therapist nurses and the working institution a linkage of individual and collective needs, so that it is possible to develop learning and career planning programs.

The accomplishment of a graduation and the continuity of the studies gave the nurses a more promising career with promotions, managerial and leadership positions, or even a career redirection.

It is observed that the work environment influences the decision to accomplish the specialty, either by the demand for assistance or by the discovery of personal and professional affinities.

It was found that enterostomal therapy is inserted in several types of institutions and that the positions of enterostomal therapist nurses are diverse, presenting a range of choice for those who want to pursue a career in the area. The specialty provides career opportunities for nurses in areas not so traditional, such as industry and self-employment itself in clinics and home care.

It is understood that enterostomal therapist nurses seek better opportunities with the continuity of studies, pursuing scientific and practical knowledge to better serve the clientele and also try to share their knowledge with new enterostomal therapists, thus expanding the specialty. 
Further research with a larger sample size is of utmost importance to observe the reflections on the career of enterostomal therapist nurses.

\section{ACKNOWLEDGMENTS}

To the participants who volunteered to contribute to this research.

\section{AUTHOR'S CONTRIBUTION}

Conceptualization: Paula MAB; Wojastyk LDMC and Prado MNB; Methodology: Paula MAB; Investigation: Wojastyk LDMC and Prado MNB; Writing - Original Draft: Wojastyk LDMC and Prado MNB; Writing - Review and Editing: Paula MAB; Wojastyk LDMC and Prado MNB; Supervision: Paula MAB.

\section{REFERENCES}

1. Ortega MCB, Cecagno D, Llor AMS, Siqueira $\mathrm{HCH}$, Montesinos MJL, Soler LM. Academic training of nursing professionals and its relevance to the workplace. Rev Latino-Am Enfermagem. 2015;23(3):404-10. https://doi. org/10.1590/0104-1169.0432.2569

2. Messias M, Gonçalves GCC, Lecca CGG, Ciampone MHT, Mira VL. Identificação das âncoras de carreira de enfermeiros. RECOM. 2017;7:e1104. https://doi.org/10.19175/recom. $\checkmark 7 \mathrm{i} 0.1104$

3. Paula MAB, Ribeiro SLS, Santos VLCG. Who and where are specialist nurses in enterostomal therapy in Brazil? ESTIMA, Braz J Enterostomal Ther. 2019;17:e2419. https://doi. org/10.30886/estima

4. Costa COM, Squarcina DF, Paula MAB. O especialista em estomaterapia. In: Paula MAB, Paula PR, Cesaretti IUR, organizadores. Estomaterapia em foco e o cuidado especializado. São Caetano do Sul: Yendis; 2014. p.1-12.

5. Paula MAB, Santos VLCG. O significado de ser especialista para o enfermeiro estomaterapeuta. Rev Latino-Am Enfermagem. 2003;11(4):474-82. https://doi.org/10.1590/ S0104-11692003000400010

6. [SOBEST] Associação Brasileira de Estomaterapia: feridas, estomias e incontinência. Diretrizes éticas para o exercício da estomaterapia. [cited on 26 jun. 2020]. Available at: http:// www.sobest.org.br/arquivos/codigo-de-etica-sobest.pdf

7. Brasil. Conselho Nacional de Saúde. Resolução nº. 466 de 12 de dezembro de 2012. Diretrizes e normas regulamentadoras de pesquisa envolvendo seres humanos. 2012. [cited on 10 oct. 2015. Available at: http://www. conselho.saude.gov.br/resolucoes/2012/Reso466.pdf
8. Sphinx Brasil. Survey - Software para análise de dados quantitativos [cited on 10 feb. 2015]. Available at: https:// www.sphinxbrasil.com/

9. [Cofen] Conselho Federal de Enfermagem. Pesquisa Perfil da Enfermagem no Brasil. 2015. [cited on 20 oct. 2019]. Available at: http://www.cofen.gov.br/perfilenfermagem/ index.html

10. Costa RRO, Medeiros SM, Santos VEP, Feijão AR, Bosco Filho J, Araújo MS. Positivismo e Complexidade: Interfaces e influências no contexto do ensino da graduação em enfermagem. Rev Baiana Enferm. 2017;31(1):e17067.

11. [IBGE] Instituto Brasileiro de Geografia e Estatística. Brasília. 2019. [cited on 3 oct. 2019]. Available at: http://www.ibge. gov.br/home/estatistica/indicadores.php

12. Paula, MAB. Reflexão - A Prática do Especialista na Diversidade. ESTIMA, Braz J Enterostomal Ther. 2008;6(4):33-4.

13. Liu L-X, Wang L. A review of the development and current status of wound ostomy continence nurses in the mainland of China. Int J Nurs Sci. 2018;5(2):105-9. https://doi. org/10.1016/j.ijnss.2018.03.002

14. Dias MSC, Paula MAB, Morita, ABPS. Perfil Profissional de Enfermeiros Estomaterapeutas Egressos da Universidade de Taubaté. ESTIMA, Braz J Enterostomal Ther. 2014;12(3):1.

15. Kleinpell R, Scanlon A, Hibbert D, Ganz FDK, East L, Fraser $D$, et al. Addressing Issues Impacting Advanced Nursing Practice Worldwide. Online J Issues Nurs. 2014;19(2):5.

16. Rodrigues CLMM. A relação entre percepção de sucesso na carreira e qualidade de vida no trabalho: um estudo comparativo com médicos que atuam na cidade Belo Horizonte [dissertação]. [Belo Horizonte]: Universidade FUMEC; 2016. 